\title{
O USO DO COMPUTADOR COMO INSTRUMENTO DE ENSINO DE ESCRITA PARA ALUNOS SURDOS
}

\author{
Adrielle Martins de Souza; Karen F. de Mesquita Ribeiro e Juliene Borges dos Santos (IC EM) \\ Orientadora: Profa. Dra. Ivani Rodrigues Silva
}

\section{Resumo}

Entender a importância do uso das novas tecnologias para o contexto da surdez é algo válido, pois pode ajudar o aluno surdo na assimilação de conteúdos e fazê-los compreender melhor o funcionamento da língua portuguesa e de outros conteúdos escolares. O objetivo inicial desse trabalho foi mapear o uso das novas tecnologias por alunos surdos do Ensino Médio e verificar como eles as utilizavam para fins pedagógicos. A partir disso, explorar novos usos dessas tecnologias, enfatizando a leitura e a escrita em língua portuguesa, propondo aos alunos surdos produção de um material utilizando as novas tecnologias, no caso, um blog.

Palavras Chave: alunos surdos, novas tecnologias, leitura/escrita.

\section{Introdução}

As novas tecnologias são parte essencial do cotidiano moderno, principalmente de jovens em período escolar. Considerando a comunidade surda e a educação de surdos, foco desse projeto, os multiletramentos $e$ as novas tecnologias se mostram essenciais no projeto pedagógico. Sendo o surdo usuário de uma língua diferente da língua da maioria ouvinte ao seu redor, e sendo essa língua - a LIBRAS - de características visuais, é importante para 0 sucesso da aprendizagem do aluno surdo que elementos de características visuais estejam presentes no projeto pedagógico, como imagens e vídeos. Assim, por apresentar a tela como suporte, as novas tecnologias - representadas pelos computadores, tablets e smartphones permite que esses elementos visuais sejam incorporados a sala de aula. Além disso, com o avanço da internet, as novas tecnologias e os multiletramentos permitem que $o$ acesso a rede e as experiências que ela pode proporcionar se tornem mais presentes. Por meio da internet, é possível que 0 aluno acesse links e hyperlinks sobre o assunto tratado em aula e, assim, abra novos caminhos de aprendizagem.

\section{Resultados e Discussão}

A primeira etapa do projeto foi mapear, por meio de entrevistas e observações, como é feito o uso das novas tecnologias pelos alunos surdos. As entrevistas foram respondidas por 7 alunos do grupo, incluindo os participantes desse projeto. As respostas foram organizadas nas tabelas a seguir A partir desses dados coletados, buscamos formular novas estratégias que incentivem o uso das novas tecnologias nas práticas de letramento. Percebemos que a criação de um blog seria eficaz para atingir o objetivo. O blog é uma ferramenta virtual que pode ser acessada de qualquer dispositivo eletrônico, tanto computadores/notebooks como tablets e celulares/smartphones, e permite a utilização não só de textos escritos, como também de vídeos, imagens e sons. Assim, chegamos a conclusão de que por meio da construção de um blog, podemos aproximar os alunos surdos das diferentes formas de linguagem e de letramentos presentes na internet.

\section{Conclusões}

Podemos perceber que as novas tecnologias são bastante utilizadas pelos alunos surdos em fase escolar e são utilizadas para diversas finalidades, como entretenimento, redes sociais e pesquisas escolares. Com a construção do blog, tivemos a oportunidade de deslocarmos nossa posição sujeito, já que além de receptores de conhecimento, também nos tornamos autores, de modo que manifestamos nossa opinião sobre os diversos temas que abordamos. Assim, acreditamos que a construção do blog e o acesso às novas tecnologias é uma forma eficaz de letramento em língua portuguesa para alunos surdos.

\section{Agradecimentos}

Ao PIBIC/CNPQ por tornar possivel esse trabalho e por estimular e proporcionar rico aprendizado e experiência aos alunos surdos.

LEMKE, J. Letramento metamidiático: transformando significados e mídias. Trabalhos em Linguística Aplicada, Vol. 49(2): 455-479. Campinas: Julho/Dez, 2010. Disponível em: http://www.scielo.br/pdf/tla/v49n2/09.pdf.

ROJO, R. H. R. (Org.). Escol@ conect@d@: os multiletramentos e as TICs. São Paulo: Parábola Editorial, 2013, p. 13-36 